
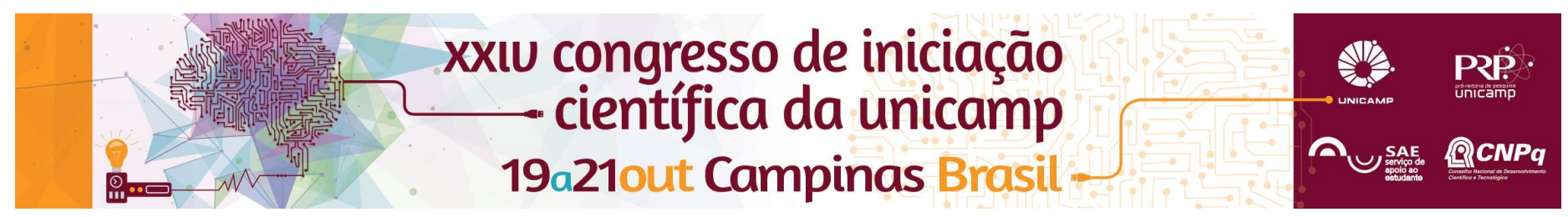

\title{
O potencial de difusão de sistemas agroflorestais no território brasileiro
}

\section{Yan Prada Moro*}

\section{Resumo}

O seguinte trabalho tem como principal objetivo analisar a capacidade de desenvolvimento de sistemas agroflorestais no Brasil. Essa análise esta fundamentada em indicadores financeiros, como Valor Presente Líquido (VPL), Relação Benefício/Custo (B/C), Taxa Interna de Retorno (TIR) e Valor Estatuto da Terra (VET). Estes indicadores foram utilizados para dados reais de trabalhos de agrofloresta desenvolvidos principalmente pela EMBRAPA, em diversas regiões brasileiras.

\section{Palavras-chave: \\ Agrofloresta, EMBRAPA, indicadores financeiros.}

\section{Introdução}

O governo brasileiro necessita apostar em novas formas de proodução agricola, frente aos cambios climáticos e a insustentabilidade de longo prazo do sistema produtivo agrícola atual.

Os maiores problemas ambientais do Brasil são consequencia de uma agricultura itinerante e devastadora para o solo, para a agua e para os demais seres vivos.

Dessa forma, o presente trabalho busca exemplos de políticas públicas internacionais eficazes ao desenvolvimento de sistemas agroflorestais, como é o caso da Costa Rica, além de expor também a viabiidade económica de projetos agroflorestais realizados pela EMBRAPA para diversas regiões do Brasil.

\section{Objetivo:}

O principal objetivo da pesquisa é reunir trabalhos sobre a viabilidade financeira das agroflorestas, realizados principalmente pela EMBRAPA nas diversas regiões do Brasil. Tais estudos devem evidenciar os problemas de cada região para implementar sistemas agroflorestais.

\section{Resultados e Discussão}

Como resultados, identificamos a carencia de políticas públicas brasileiras para projetos de sistemas agroflorestais. Demonstramos que essas políticas podem trazer benefícios aos países que as aplicam, como ocorreu, por exemplo, com a Costa Rica.

Outro resultado importante é a constatação de que os maiores custos de implementação de sistemas agroflorestais são os de mão de obra, principalmente nos primeiros anos. Todavía, sistemas de culturas perenes e altos custos de mão de obra são os que apresentaram melhores desempenhos economicos.

\section{Conclusão}

Os trabalhos estudados nesta tese lidam com diversos projetos de plantio em diferentes regiões brasileiras, com os mais variados climas, vegetações e consórcios. Contemplam regiões de expansão da fronteira agrícola, assim como regiões já totalmente ocupadas e desmatadas. Mesmo com essa variedade, todos os projetos abordados provaram-se viáveis economicamente.

Como maneira de conclusão, temos que os maiores custos dos sistemas, devido a sua maior complexidade, não significam pior desempenho econômico. Um dos maiores problemas, todavia, é a situação da oferta de mão-de-obra no campo, que vem mudando rapidamente em função do êxodo rural e, principalmente, do colapso demográfico do país.

Dessa forma, como conclusão geral, pode-se afirmar que as práticas agroflorestais são viáveis economicamente no território agrícola brasileiro, tanto para o reflorestamento como para o cultivo de árvores e para as culturas agrícolas.

O Brasil, nesse caminho, ainda necessita evoluir muito nas práticas agrícolas mais sustentáveis e em harmonia com a natureza. Mas, como se apontou, há diversos atores que se encontram ativos nessa jornada em prol da sustentabilidade: pesquisadores da EMBRAPA e agricultores de diversas regiões do país.

\section{Agradecimentos}

Agradeço ao apoio economico concedico pelo Cnpq e ao apoio intelectual concedido pelo orientador Ademar Ribeiro Romero 